\title{
Influence of VEGFR single nucleotide polymorphisms on the efficacy of sunitinib therapy against renal cell carcinoma
}

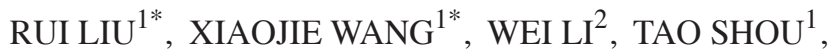 \\ LIKUN ZHOU $^{3}, \mathrm{YUNFEN} \mathrm{LI}^{4}, \mathrm{MING} \mathrm{BAI}^{3}$ and QIANG PEI ${ }^{5}$
}

\begin{abstract}
Departments of ${ }^{1}$ Oncology and ${ }^{2}$ Urological Surgery, The First People's Hospital of Yunnan Province, Kunming, Yunnan 650032; ${ }^{3}$ Department of Gastrointestinal Medical Oncology, Tianjin Medical University Cancer Institute and Hospital, Tianjin 300060; ${ }^{4}$ Department of Radiotherapy, The Third Affiliated Hospital of Kunming Medical University, Yunnan Cancer Hospital, Kunming, Yunnan 650118; ${ }^{5}$ Department of Hematology, The First People's Hospital of Yunnan Province, Kunming, Yunnan 650032, P.R. China
\end{abstract}

Received April 8, 2016; Accepted September 16, 2016

DOI: $10.3892 / \mathrm{ol} .2016 .5396$

\begin{abstract}
Single nucleotide polymorphisms (SNPs) of vascular endothelial growth factor receptor (VEGFR) may have effects on the MAPK/ERK/STAT3 signaling pathway, and the resulting phenotypes may influence the response to sunitinib-targeted therapy for renal cell carcinoma. In order to test this hypothesis patients with advanced renal cell carcinoma treated with sunitinib, were enrolled in our study. Peripheral blood samples were used to run a polymerase chain reaction-restriction fragment length polymorphism protocol to type candidate nucleotide polymorphism loci (VEGFR1, VEGFR2 and VEGFR3). The samples were also used in western blots to determine p-MAPK/ERK/STAT3 protein expression levels. The clinical responses to treatment were recorded and then a logistic regression method was applied to analyze the correlation between polymorphism of loci and effectiveness of sunitinib therapy. According to a follow-up visit (on average after 15 months of treatment) there were 16 complete responses (CR), 29 partial responses (PR) and 23 stable disease (SD) and progression of disease (PD) cases. Tests were carried out for 5 SNPs: VEGFR1 (rs664393), VEGFR2 (rs1870377 and rs7667298) and VEGFR3 (rs448012 and rs72816988). Mutation rates of rs1870377 and rs448012 loci in the $\mathrm{CR}+\mathrm{PR}$ group were lower than those in the SD+PD group. No such differences were found for the other 3 loci. Relative expression levels of p-MAPk, p-ERK and p-STAT3
\end{abstract}

Correspondence to: Dr Qiang Pei, Department of Hematology, The First People's Hospital of Yunnan Province, 157 Jinbi Road, Kunming, Yunnan 650032, P.R. China

E-mail: peiqiang828@163.com

*Contributed equally

Key words: vascular endothelial growth factor receptor, single nucleotide polymorphism, MAPK/ERK/STAT3 signaling pathway, sunitinib, targeted therapy, renal cell carcinoma in the $\mathrm{CR}+\mathrm{PR}$ group were significantly lower than those in the $\mathrm{SD}+\mathrm{PD}$ group $(\mathrm{P}<0.05)$. The median progression-free survival and overall survival (OS) in the $\mathrm{CR}+\mathrm{PR}$ group were higher than those in the SD+PD group $(\mathrm{P}<0.001)$. The median OS of the TT rsl870377 genotype was higher than that of the AA genotype, and the median OS of the GG rs448012 genotype was higher than that of the CC genotype $(\mathrm{P}<0.001)$. It was concluded through a logistic regression model that rs1870377 (AA) and rs448012 (GG) are independent risk factors closely associated with the effectiveness of sunitinib-targeted therapy on renal cell carcinoma. VEGFR SNPs are able to mediate the MAPK/ERK/STAT3 signaling pathway and therefore influence the effectiveness of sunitinib-targeted therapy, which makes them possible new therapeutic targets.

\section{Introduction}

Renal cell carcinoma is one of the most common malignant tumors of the urinary system. Its global incidence rate has been increasing steadily every year and $20-30 \%$ of patients cannot be treated with radical operation because they have distant metastases at the time of diagnosis (1). Renal cell carcinoma is known for being insensitive to chemo- and radiotherapy. Sunitinib (sunitinib malate) targeted therapy, represented by multi-target tyrosine kinase inhibitors, has good clinical effects on treating advanced renal cell carcinoma and has been applied as a first-line treatment drug (2). However, previous findings showed the effective rate to be only $60-75 \%$, leaving many patients to undergo ineffective treatment with added secondary adverse reactions (3). A study has found that individual single nucleotide polymorphisms (SNPs) can influence signaling pathways such as MAPK/ERK/STAT3 and determine whether sunitinib therapy will be effective against renal cell carcinoma (4). The tumor in renal cell carcinoma is generally highly vascular and notably expresses vascular endothelial growth factors (VEGFs) and their receptors (5).

The present study focused on specific SNPs, namely VEGFR1, VEGFR2 and VEGFR3, which hypothetically have an impact on the MAPK/ERK/STAT3 signaling pathways and influence sunitinib renal cell carcinoma treatment, with the 
hope of contributing to a better understanding of the pathogenesis of the cancer and allow for more effective treatment adjustments.

\section{Subjects and methods}

Patients and methods. A total of 68 patients treated for advanced renal cell carcinoma in our hospital from January, 2014 to July, 2015 participated in the present study. The following cases were excluded: Patients with kidney failure, history of surgical and chemoradiotherapy treatments, additional malignant tumors, severe condition, predicted survival $<12$ months, sunitinib course of $<3$ months, and incomplete data. The Ethics Committee of the First People's Hospital of Yunnan Province approved the study and the patients signed informed consent. There were 40 male and 28 female cases, aged between 46 and 72 years (with an average of $62.3 \pm 14.5$ years); the disease had been present for 1-5 months (with an average of $2.3 \pm 1.2$ months); the Karnofski performance status scoring ranged from 62 to 86 points ( $74.5 \pm 8.9$ points in average); and metastases were present in the following organs: 23 lung metastases, 19 lymphatic metastases, 10 osseous metastases, 10 hepatic and adrenal metastases and 6 other metastases.

The dosage plan of sunitinib for each patient was $50 \mathrm{mg} /$ day taken orally for 4 weeks, drug withdrawal for 2 weeks, and then restarting the cycle for $\geq 3$ months.

Assessment of response to therapy. The RECIST 1.0 standard was used to evaluate the tumor lesions, dividing radiological results into: Complete response (CR), partial response (PR), stable disease (SD) and progression of disease (PD) and evaluating every 6 weeks ( 1 cycle). Adverse effects were evaluated based on the NCI-CTC AE3.0 standard. Progression-free survival (PFS) includes the time from the beginning of treatment until PD or death and overall survival (OS) is the time from the beginning of treatment to death.

Testing index and method. Polymerase chain reaction-restriction fragment length polymorphisms (PCR-RFLPs) were used to determine candidate nucleotide polymorphism loci (VEGFR1, VEGFR2 and VEGFR3), and western blotting was performed to test the $\mathrm{p}-\mathrm{MAPK} / \mathrm{ERK} / \mathrm{STAT} 3$ protein expression levels.

Peripheral venous blood $(5 \mathrm{ml})$ was drawn from each patient after overnight fasting of $\geq 8 \mathrm{~h}$ and stored at $-20^{\circ} \mathrm{C}$. QIAamp DNA kit was used to extract the DNA and protease $\mathrm{K}$ was used for sample digestion. An equilibrated-phenol extraction method was used to purify concentrated DNA; the genetic typing was accomplished in a double-blind fashion by two people. The SNPs VEGFR1, VEGFR2 and VEGFR3 were selected for sequencing. The screening standards were as follows: Gene frequency for Chinese people $>5 \%$, linkage disequilibrium principle of didymous SNP loci and related coefficient $\mathrm{r}^{2}>0.8$.

The reagents for PCR-RFLP included TaqDNA polymerase, dNTPs, and a DNA fragment length standard (PCR markers), were purchased from Nanjing KeyGen Biotech Co., Ltd., (Nanjing, China); a restriction enzyme was purchased from Fermentas (Glen Burnie, MD, USA). The Primer Premier 5.0 software was used for primer design (Premier Biosoft International, Palo Alto, CA, USA) and primers were
Table I. Restriction enzyme used in the PCR-RFLP method.

$\begin{array}{lc}\text { Gene } & \begin{array}{c}\text { Restriction } \\ \text { enzyme }\end{array} \\ \text { name } & \text { Primers 5'-3' }\end{array}$

\section{VEGFR1}

$\begin{array}{lll}\text { rs664393 SciI } & \text { F-GACTAAACACCCCTCCAGCA } \\ & \text { R-TGTCAGCATTGTCCTTCTGC }\end{array}$

\section{VEGFR2}

$\begin{array}{lll}\text { rs1870377 } & \text { AluI } & \text { F-TTTCCTCCCTGGAAGTCCTC } \\ & & \text { R-GGCTGCGTTGGAAGTTATTT } \\ \text { rs7667298 } & \text { Hpy8I } & \text { F-ATCCTTGGTCACTCCGGTTT } \\ & & \text { R-TGCTGTGCTTTGGAAGTTCA }\end{array}$

\section{VEGFR3}

$\begin{array}{lll}\text { rs448012 } & \text { SatI } & \text { F-GAGGTTGACCACGTTGAGGT } \\ & & \text { R-TTCAGAGCCGAGGGACCA } \\ \text { rs72816988 } & \text { SsiI } & \text { F-TGTGGGGGCTGTTCTGTATT } \\ & & \text { R-ACCTCTGCTCCCTTCTCCTC }\end{array}$

PCR-RFLP, polymerase chain reaction-restriction fragment length polymorphism; VEGFR, vascular endothelial growth factor receptor.

synthesized by Shanghai Invitrogen Biotechnology Co., Ltd. (Shanghai, China) (Table I). MJ-PTC200 type PCR amplification apparatus was used with each test tube reaction containing $10 \mu \mathrm{l}$ (including $50 \mathrm{ng}$ genome DNA in $5 \mu \mathrm{l}, 2 \mathrm{X}$ Taq PCR Mix, $0.15 \mu \mathrm{l}$ of $10 \mathrm{pmol} / \mu \mathrm{l}$ upstream and downstream primers, $4.2 \mu \mathrm{l} \mathrm{ddH_{2 }}$ O). The PCR reaction protocol was programmed as: Initial pre-denaturation step at $94^{\circ} \mathrm{C}$ for $5 \mathrm{~min}$, followed by 34 cycles of a denaturing step at $94^{\circ} \mathrm{C}$ for $30 \mathrm{sec}$, an annealing step at $59^{\circ} \mathrm{C}$ for $40 \mathrm{sec}$, and an extension $72^{\circ} \mathrm{C}$ for $45 \mathrm{sec}$, and a final extension at $72^{\circ} \mathrm{C}$ for $10 \mathrm{~min}$. Then, $2 \%$ agarose gel electrophoresis was prepared to observe the PCR product. The prepared enzymatic digestion system included: 5 units of

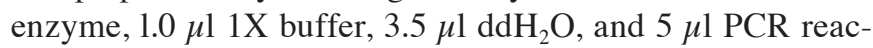
tion product. The mixtures were incubated at $37^{\circ} \mathrm{C}$ thermostat overnight and the next morning a $3 \%$ sepharose gel was electrophoresed to visualize the enzymatic digestion results and identify the genotypes under a UV lamp.

For western blotting, RIPA cell lysis buffer and PMSF (protease inhibitor) were used to extract proteins (both reagents were from Shenneng Bocai Biotechnology Co., Ltd., Shanghai, China); the Bradford method was used to test the protein sample concentrations (kit from R\&D Systems, Inc., Minneapolis, MN, USA); the samples were loaded onto 5X SDS-PAGE electrophoresis gels (loading buffer from Beyotime Institute of Biotechnology, Shanghai, China) and run; and Coomassie brilliant blue (from Beijing Zhongshan Co., Beijing, China) was used to stain the gels. After membrane transfer; the immunoreaction was set up. Briefly, the PVDF membrane in a glass container was soaked with $5 \%$ blocking buffer, and agitated at $25^{\circ} \mathrm{C}$ for $1 \mathrm{~h}$. The primary mouse antihuman monoclonal antibodies (Santa Cruz Biotechnology, Inc., Dallas, TX, USA) were added to the buffer at appropriate concentrations [p-MAPK (cat. no. SC-6802) was added at a 1:2,000 concentration, $\mathrm{p}-\mathrm{ERK}$ antibody (cat. no. SC-154) at a 
Table II. SNP sequencing results.

\begin{tabular}{|c|c|c|c|c|c|c|c|}
\hline $\begin{array}{l}\text { Gene } \\
\text { type }\end{array}$ & $\begin{array}{l}\text { Locus } \\
\text { mutation }\end{array}$ & $\begin{array}{l}\text { Gene frequency } \\
\text { of minor allele }\end{array}$ & $\begin{array}{c}\text { Mutation rate } \\
\text { [case }(\%)]\end{array}$ & $\begin{array}{l}\text { CR+PR group } \\
\quad(n=45)\end{array}$ & $\begin{array}{l}\text { SD+PD group } \\
\quad(n=23)\end{array}$ & $\chi^{2}$ & $\mathrm{P}$-value \\
\hline $\begin{array}{l}\text { VEGFR1 } \\
\text { rs664393 }\end{array}$ & $\mathrm{G}>\mathrm{A}$ & 0.244 & $13(19.1)$ & $9(20.0)$ & $4(17.4)$ & 0.000 & 1.000 \\
\hline $\begin{array}{l}\text { VEGFR2 } \\
\text { rs1870377 } \\
\text { rs7667298 }\end{array}$ & $\begin{array}{l}\mathrm{A}>\mathrm{T} \\
\mathrm{C}>\mathrm{T}\end{array}$ & $\begin{array}{l}0.467 \\
0.284\end{array}$ & $\begin{array}{l}31(45.6) \\
15(22.1)\end{array}$ & $\begin{array}{r}15(33.3) \\
8(17.8)\end{array}$ & $\begin{array}{r}16(69.6) \\
7(30.4)\end{array}$ & $\begin{array}{l}8.055 \\
1.418\end{array}$ & $\begin{array}{l}0.005 \\
0.234\end{array}$ \\
\hline $\begin{array}{l}\text { VEGFR3 } \\
\text { rs448012 } \\
\text { rs72816988 }\end{array}$ & $\begin{array}{l}\mathrm{C}>\mathrm{G} \\
\mathrm{G}>\mathrm{A}\end{array}$ & $\begin{array}{l}0.483 \\
0.079\end{array}$ & $\begin{array}{r}29(42.6) \\
7(10.3)\end{array}$ & $\begin{array}{c}14(31.1) \\
3(6.7)\end{array}$ & $\begin{array}{r}15(65.2) \\
4(17.4)\end{array}$ & $\begin{array}{l}7.239 \\
0.912\end{array}$ & $\begin{array}{l}0.007 \\
0.340\end{array}$ \\
\hline
\end{tabular}

SNPs, single nucleotide polymorphisms; CR, complete response; PR, partial response; SD, stable disease; PD, progression of disease.

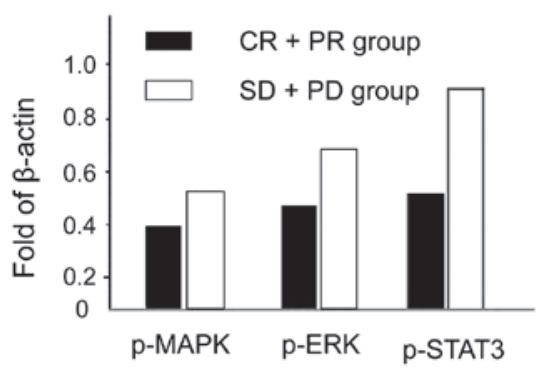

Figure 1. Expression levels of p-MAPK/ERK/STAT3 in different reaction groups analyzed by western blotting (levels normalized to the in-house $\beta$-actin protein levels). CR, complete response; PR, partial response; SD, stable disease; $\mathrm{PD}$, progression of disease.

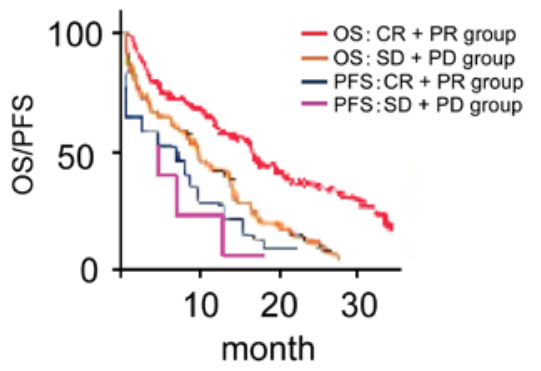

Figure 2. Comparison of progression-free survival (PFS) and overall survival (OS) in different reaction groups. $\mathrm{CR}$, complete response; PR, partial response; $\mathrm{SD}$, stable disease; $\mathrm{PD}$, progression of disease.

1:300 concentration, $\mathrm{p}-\mathrm{STAT} 3$ (cat. no. SC-7179) at a 1:1,000 concentration and $\beta$-actin (cat. no. SC-47778) at a 1:500 concentration] and were stored at $4^{\circ} \mathrm{C}$ overnight. The following day, the PVDF membranes were washed three times in PBST for $10 \mathrm{~min}$. Blocking buffer was used to prepare secondary antibody goat anti-mouse IgG marked by horseradish peroxidase (Santa Cruz Biotechnology, Inc.; cat. no. SC-2054) at a 1:1,000 concentration, and the PVDF membranes were soaked at $37^{\circ} \mathrm{C}$ on a shaking platform for $2 \mathrm{~h}$. Finally, after washing the membranes three times in PBST, the blots were visualized by chemiluminescence (ECL fluorescence detection kit from
Beyotime Institute of Biotechnology), and the results were scanned into a computer through a gel imager and analyzed using Quantity One 4.4.0 software. The experiments were done in triplicate and the values obtained are averages of three experiments. After processing, reported values represent the average of OD value ratios between the target protein and the $\beta$-actin protein bands for normalization.

Statistical analysis. Data were processed through SPSS 19.0 statistical software (SPSS, Inc., Chicago, IL, USA). Measurement data were shown as mean value \pm standard deviation and comparison among groups was through t-test. Enumeration data are shown as cases or percentages and comparison among groups were carried out using the (correction) $\chi^{2}$ test. The logistic regression method was used to analyze the correlation between SNPs and the effectiveness of sunitinib-targeted therapy on renal cell carcinoma and the step-back technique was used for screening. The comparison of PFS and OS was analyzed by the Kaplan-Meier method; $\mathrm{P}<0.05$ was considered to indicate a statistically significant difference.

\section{Results}

SNP sequencing results. The elapsed time before the follow-up visits ranged from 6 to 23 months, and the median time was 15 months. Of the 68 patients, there were 16 CR cases, 29 PR cases and 23 SD and PD cases. Tested SNP mutation sites and mutation rates are shown in Table II. Mutation rates of rsl870377 and rs448012 loci in the CR+PR group are lower than those in the SD+PD group while there are no differences for the other 3 loci.

Comparison of $p$-MAPK/ERK/STAT3 expression levels. The expression levels for p-MAPK, p-ERK and p-STAT3 in the the $\mathrm{CR}+\mathrm{PR}$ group are lower than those in the SD+PD group and the differences are of statistical significance $(\mathrm{P}<0.05$; Fig. 1).

Comparison of PFS and OS in different reaction groups. Median PFS and OS in CR+PR group are significantly higher than those in SD+PD group (comparing 9.6 months with 
Table III. Analyzing correlation between SNP and OS with logistic regression method.

\begin{tabular}{lccrrr}
\hline SNPs & B & Wald & P-value & OR & $95 \%$ CI \\
\hline rs664393 & 0.321 & 1.302 & 0.616 & 0.427 & $-0.325-2.302$ \\
rs1870377 & 0.108 & 6.957 & $<0.001$ & 3.526 & $2.852-5.629$ \\
rs7667298 & 0.254 & 2.625 & 0.938 & 0.854 & $0.232-3.935$ \\
rs448012 & 0.163 & 7.854 & $<0.001$ & 4.113 & $3.593-5.942$ \\
rs72816988 & 0.096 & 1.429 & 0.532 & 0.322 & $-0.528-2.534$ \\
\hline
\end{tabular}

SNPs, single nucleotide polymorphisms; OS, overall survival; B, regression coefficient; OR, odds ratio; CI, confidence interval.

6.2 months, $\chi^{2}=8.924, \mathrm{P}<0.001$; comparing 17.5 months with 11.3 months, $\chi^{2}=10.548, \mathrm{P}<0.001$; Fig. 2).

Association between SNPs and OS. The median OS of the rs1870377 genotype TT was obviously higher than that for the genotype AA, and the median OS of rs448012 genotype GG was higher than that for the genotype $\mathrm{CC}$. The differences are of statistical significance (comparing 15.8 months with 9.5 months, $\chi^{2}=16.432, \mathrm{P}<0.001$; comparing 24.3 months with 17.2 months, $\chi^{2}=12.623, \mathrm{P}<0.001$; Fig. 3 ).

Correlation between SNP and effectiveness analyzed by logistic regression method. Taking the abovementioned 5 SNPs as independent variables and the effectiveness of $\mathrm{CR}+\mathrm{PR}$ as the dependent variable, it was concluded by a multi-factor logistic regression model that rs1870377 and rs448012 are closely associated with the effectiveness of sunitinib-targeted therapy on renal cell carcinoma, and that A mutation of rs1870377 and $\mathrm{C}$ mutation of rs448012 are independent risk factors that influence treatment efficacy (Table III).

\section{Discussion}

Sunitinib is able to block vascular VEGF receptors, platelet-derived growth factor receptors (PDGFR- $\alpha$ and PDGFR- $\beta$ ), the stem cell factor receptor (C-kitR), FMS-like tyrosine kinase-3, the type I colony stimulating factor receptor and the neurotrophin receptor derived from neural glial cells, strongly inhibiting proliferation of tumor cells and exerting an anti-angiogenesis effect $(6,7)$. In addition, sunitinib is able to inhibit tumor cell proliferation directly by inhibiting several signal transduction pathways such as Ras/Raf/MEK/ERK and MAPK/ERK/STAT3 $(8,9)$; directly inducing mechanisms such as tumor cell apoptosis (10), leading to a multi-targeted treatment on advanced renal cell carcinoma. Sunitinib has been approved by the FDA in the USA and by the European Commission to be used in the treatment of advanced renal cell carcinoma.

Most molecular-targeted drug treatments have some positive effects but bear low complete remission rates, which may be due to SNPs (11). SNPs are able to influence functions by modifying gene structures and may lead to increased risks of developing tumors (12). It has been shown that the function of genes related to angiogenesis such as VEGFA and VEGFR can be linked to risks of renal carcinoma due to adjustments in the expression levels of other genes (13). A study found that
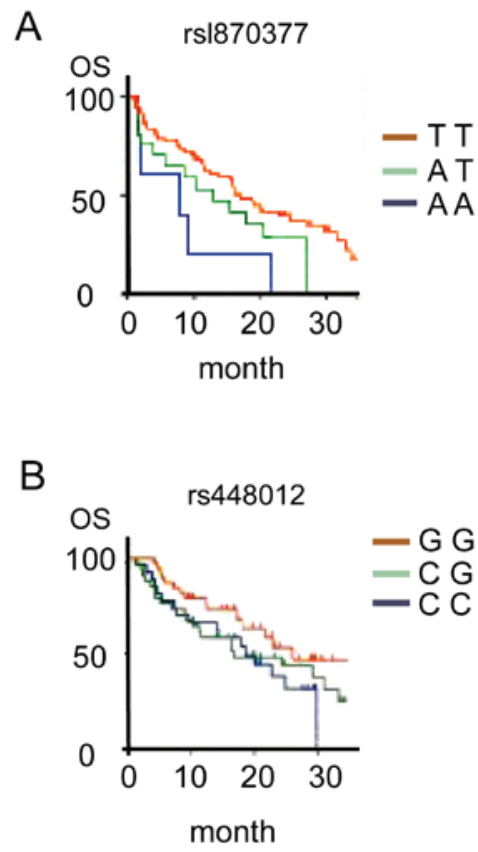

Figure 3. Association between single nucleotide polymorphisms and overall survival (OS). (A) Association between rs1870377 polymorphism and OS; (B) Association between rs448012 polymorphism and OS.

the 460th gene polymorphism of VEGF is a risk factor for renal carcinoma (14). Another study, using a genome-wide association in European population, found three loci related to susceptibility to renal carcinoma, one of which is in the $2 \mathrm{p} 21$ region (rs7579899) and encodes the endothelial PAS constitutive protein 1 (EPAS1, that is HIF-2 $\alpha$ ) (15). Nevertheless, related studies have not found the same results in Chinese individuals (16), showing how genetic structures can differ for different populations.

Among the population of patients with advanced renal cell carcinoma in the present study, the mutation rates for VEGFR2 (rs1870377) and VEGFR3 (rs448012) were the highest. However, the same mutation rates in the subgroup of $\mathrm{CR}+\mathrm{PR}$ patients were lower than those in the SD+PD subgroup. Also, the relative expression levels of p-MAPK, p-ERK and p-STAT3 in the better response group were significantly lower. Moreover, the median OS for the TT genotype at rs1870377 was higher than that for the AA genotype, and the median OS in the GG genotype for rs448012 was higher than that for the CC genotype. Statistical analyses 
revealed the association of these phenotypes to the effectiveness of treatment was confirmed. It is clear from the present study that VEGFR SNPs can control the MAPK/ERK/STAT3 signaling pathway protein expression and thereby influence the effectiveness of sunitinib-targeted therapy. This opens up possibilities for a new line of therapeutic targets.

\section{References}

1. Siegel R, Ward E, Brawley O and Jemal A: Cancer statistics, 2011: The impact of eliminating socioeconomic and racial disparities on premature cancer deaths. CA Cancer J Clin 61: 212-236, 2011

2. Zimmermann K, Schmittel A, Steiner U, Asemissen AM, Knoedler M, Thiel E, Miller K and Keilholz U: Sunitinib treatment for patients with advanced clear-cell renal-cell carcinoma after progression on sorafenib. Oncology 76: 350-354, 2009.

3. Motzer RJ, Hutson TE, Tomezak P, Michaelson MD Bukowski RM, Rixe O, Oudard S, Negrier S, Szczylik C, Kim ST, et al: Sunitinib versus interferon alfa in metastatic renal-cell carcinoma. N Engl J Med 356: 115-124, 2007.

4. Yamamoto K, Mizumoto A, Nishimura K, Uda A, Mukai A, Yamashita K, Kume M, Makimoto H, Bito T, Nishigori C, et al: Association of toxicity of sorafenib and sunitinib for human keratinocytes with inhibition of signal transduction and activator of transcription 3 (STAT3). PLoS One 9: e102110, 2014

5. Finley DS, Pantuck AJ and Belldegrun AS: Tumor biology and prognostic factors in renal cell carcinoma. Oncologist 16 (Suppl 2): 4-13, 2011.

6. Rock EP, Goodman V, Jiang JX, Mahjoob K, Verbois SL, Morse D, Dagher R, Justice R and Pazdur R: Food and Drug Administration drug approval summary: Sunitinib malate for the treatment of gastrointestinal stromal tumor and advanced renal cell carcinoma. Oncologist 12: 107-113, 2007.

7. Motzer RJ, Michaelson MD, Redman BG, Hudes GR, Wilding G, Figlin RA, Ginsberg MS, Kim ST, Baum CM, DePrimo SE, et al: Activity of SU11248, a multitargeted inhibitor of vascular endothelial growth factor receptor and platelet-derived growth factor receptor, in patients with metastatic renal cell carcinoma. J Clin Oncol 24: 16-24, 2006.
8. Miyake H, Muramaki M, Imai S, Harada KI and Fujisawa M: Changes in renal function of patients with metastatic renal cell carcinoma during treatment with molecular-targeted agents. Target Oncol 11: 329-335, 2016.

9. Korashy HM, Al-Suwayeh HA, Maayah ZH, Ansari MA, Ahmad SF and Bakheet SA: Mitogen-activated protein kinases pathways mediate the sunitinib-induced hypertrophy in rat cardiomyocyte H9c2 cells. Cardiovasc Toxicol 15: 41-51, 2015.

10. Shi WH, Bian YH, Song XH and WU JC: Coadministration of sorafenib with adriamycin inhibits cell proliferation in hepatocellular carcinoma cells HepG2. Prog Modern Biomed 24: 4845-3848, 2011.

11. Diekstra MH, Belaustegui A, Swen JJ, Boven E, Castellano D, Gelderblom H, Mathijssen RH, García-Donas J, Rodríguez-Antona C, Rini BI, et al: Sunitinib-induced hypertension in CYP3A4 rs4646437 A-allele carriers with metastatic renal cell carcinoma. Pharmacogenomics J 26: 2-4, 2016.

12. Diekstra MH, Swen JJ, Boven E, Castellano D, Gelderblom H, Mathijssen RH, Rodríguez-Antona C, García-Donas J, Rini BI and Guchelaar HJ: CYP3A5 and ABCB1 polymorphisms as predictors for sunitinib outcome in metastatic renal cell carcinoma. Eur Urol 68: 621-629, 2015.

13. Boers-Sonderen MJ, Desar IM, Fütterer JJ, Mulder SF, De Geus-Oei LF, Mulders PF, Van Der Graaf WT, Oyen WJ and Van Herpen CM: Biological Effects After Discontinuation of VEGFR Inhibitors in Metastatic Renal Cell Cancer. Anticancer Res 35: 5601-5606, 2015.

14. Bruyère F, Hovens CM, Marson MN, d'Arcier BF, Costello AJ, Watier H, Linassier C and Ohresser M: VEGF polymorphisms are associated with an increasing risk of developing renal cell carcinoma. J Urol 184: 1273-1278, 2010.

15. Purdue MP, Ye Y, Wang Z, Colt JS, Schwartz KL, Davis FG, Rothman N, Chow WH, Wu X and Chanock SJ: A genome-wide association study of renal cell carcinoma among African Americans. Cancer Epidemiol Biomarkers Prev 23: 209-214, 2014.

16. Harten SK, Shukla D, Barod R, Hergovich A, Balda MS, Matter K, Esteban MA and Maxwell PH: Regulation of renal epithelial tight junctions by the von Hippel-Lindau tumor suppressor gene involves occludin and claudin 1 and is independent of E-cadherin. Mol Biol Cell 20: 1089-1101, 2009. 